\title{
Xiphopterella devolii (Polypodiaceae), a new species and newly recorded genus in Taiwan
}

\author{
Shann-Jye Moore ${ }^{1 \wedge}$, Barbara S Parris², Tzu-Tong Kao ${ }^{3}$, Pi-Fong Lu ${ }^{1}$ and Wen-Liang Chiou ${ }^{3^{*}}$
}

\begin{abstract}
Background: Grammitid ferns are a tropical monophyletic clade nested in Polypodiaceae, containing more than 20 genera and more than 750 species. Many of them also grow in Taiwan. During the survey of recent two decades, an unknown grammitid fern was discovered and the taxonomic treatment is given herein.

Results: A new species, collected from Taiwan, is recognized and named, i.e., Xiphopterella devolii S. J. Moore, Parris, \& W. L. Chiou. The holotype is deposited in TAIF, and isotypes are in HAST, K, L, US, and TNS. It is also distributed on SE \& S China. The genus Xiphopterella is also a new record to Taiwan.

Conclusion: A new species, Xiphopterella devolii S. J. Moore, Parris, \& W. L. Chiou is documented herein. The Xiphopterella is a new recorded genus in Taiwan and is first found beyond Malesia regions.
\end{abstract}

Keywords: Grammitid fern; Polypodiaceae; Spore; Taiwan; Taxonomy; Xiphopterella devolii

\section{Background}

Grammitid ferns are a tropical monophyletic clade nested in Polypodiaceae (Schneider et al., 2004; Schuettpelz and Pryer, 2007; Sundue et al., 2010), containing more than 20 genera and more than 750 species (Parris, 2007). In Taiwan, six genera/17 species (DeVol, 1975), four genera/18 species (Kuo, 1985), six genera/19 species (Shieh et al., 1994; Lu and Yang, 2005), 6 genera/18 species (Yang and Liu, 2002), or 3 genera/21 species (Knapp, 2011) have been documented. Here we report a new species, Xiphopterella devolii, which is also a newly recorded genus, in Taiwan.

\section{Methods}

\section{Morphological study}

Observations and measurements of trichomes and spores were based on specimens cited herein under different kinds of microscopes.

\section{Spores}

Mature spores of Xiphopterella devolii were collected from opened sporangia on the type specimen (SJ Moore 24567) and observed with a Leitz DMR light microscope

\footnotetext{
* Correspondence: chiou@tfri.gov.tw

Deceased

${ }^{3}$ Taiwan Forestry Research Institute, 53 Nan Hai Road, Taipei 10066, Taiwan Full list of author information is available at the end of the article
}

under differential interference contrast (DIC). Diameters of 100 spores were measured. To increase the field depth of presented images, a series of photos were pictured under bright field (BF) with $2 \mu \mathrm{m}$ focus intervals and merged by Helicon Focus 4.03 (Helicon Soft). Spore topology was observed with a scanning electron microscope (SEM). The spores were spread on a cover glass coated with Stay-on adhesive (Surgipath), coated with gold by IB-2 ion coater (Eiko Engineering), and observed with a TM3000 tabletop SEM (Hitachi). The backscattered electron (BE) images were photographed under $15 \mathrm{kV}$ accelerating voltage.

\section{Trichomes}

Scales and hairs were also observed with a light microscope and SEM. To avoid damaging the type specimen (SJ Moore 24567), the whole specimens were observed under low vacuum mode of the SEM without pretreatment (i.e., fixation, dehydration, and coating).

\section{Results}

Taxonomic treatment

Xiphopterella Parris, Gard. Bull. Sing. 58(2): 249. 2007.

Plants small, epiphytic. Rhizomes radial, with stipes in whorls; scales not clathrate, pale reddish brown, glabrous. Stipe not articulate, phyllopodia absent. Lamina pinnately divided; lateral veins 1 -forked when fertile, free, 
each vein ending with a hydathode on adaxial surface. Hairs simple and 1- to 3-forked with eglandular branches. Sori superficial. Sporangia glabrous.

About seven species in the world. They are mainly distributed on Malesia regions, especially Peninsular Malaysia (Parris, 2007). The discovery of this genus beyond Malesia regions is first documented here.

Xiphopterella devolii S. J. Moore, Parris \& W. L. Chiou, sp. nov.-TYPE: TAIWAN. Ilan County, Sunglo Lake, 20 July 2000, SJ Moore 24567 (holotype: TAIF; isotype: HAST, K, L, US, TNS) Figures 1 and 2.

Plants epiphytic. Roots filamentous wiry, ca. $0.2 \mathrm{~mm}$ thick; hairs simple, shiny to brick red, 0.2-0.5 mm long. Rhizomes radial; scales pale brown to brown, ovate to lanceolate, 1-2.5 mm long, ca. $0.5 \mathrm{~mm}$ wide, not clathrate, entire, glabrous. Stipes sessile or nearly so. Laminae linear, linear-elliptic, or linear-oblanceolate, $2-7 \times 0.4-0.9 \mathrm{~cm}$, acute at apex, attenuate to form a wing at base, simple, pinnatifid; pinnatifid segment inclined or ascending, widely to narrowly triangular, slightly oblique or falcate, up to $5 \mathrm{~mm}$, entire, or rarely with a small blunt tooth at acroscopic margin; rachis prominent on abaxial side, grooved on adaxial side; lateral veins hidden, invisible, even by transmitted light, tip with a hydathode, simple in sterile segment, forked in fertile segment, acroscopic branch not extending beyond sorus; hairs transparent to pale, mainly on abaxial side of rachis and at base of laminae of young fronds, simple septate and 1 to 2 (or 3 ) forked with non-septate branches, the simple septate branch 0.1-0.2 mm long, 2-4 cells with an apical reddish club-like head, the lateral branch 0.2-0.3 $\mathrm{mm}$ long. Sori round to oval. Spores green, globose to tetrahedral-

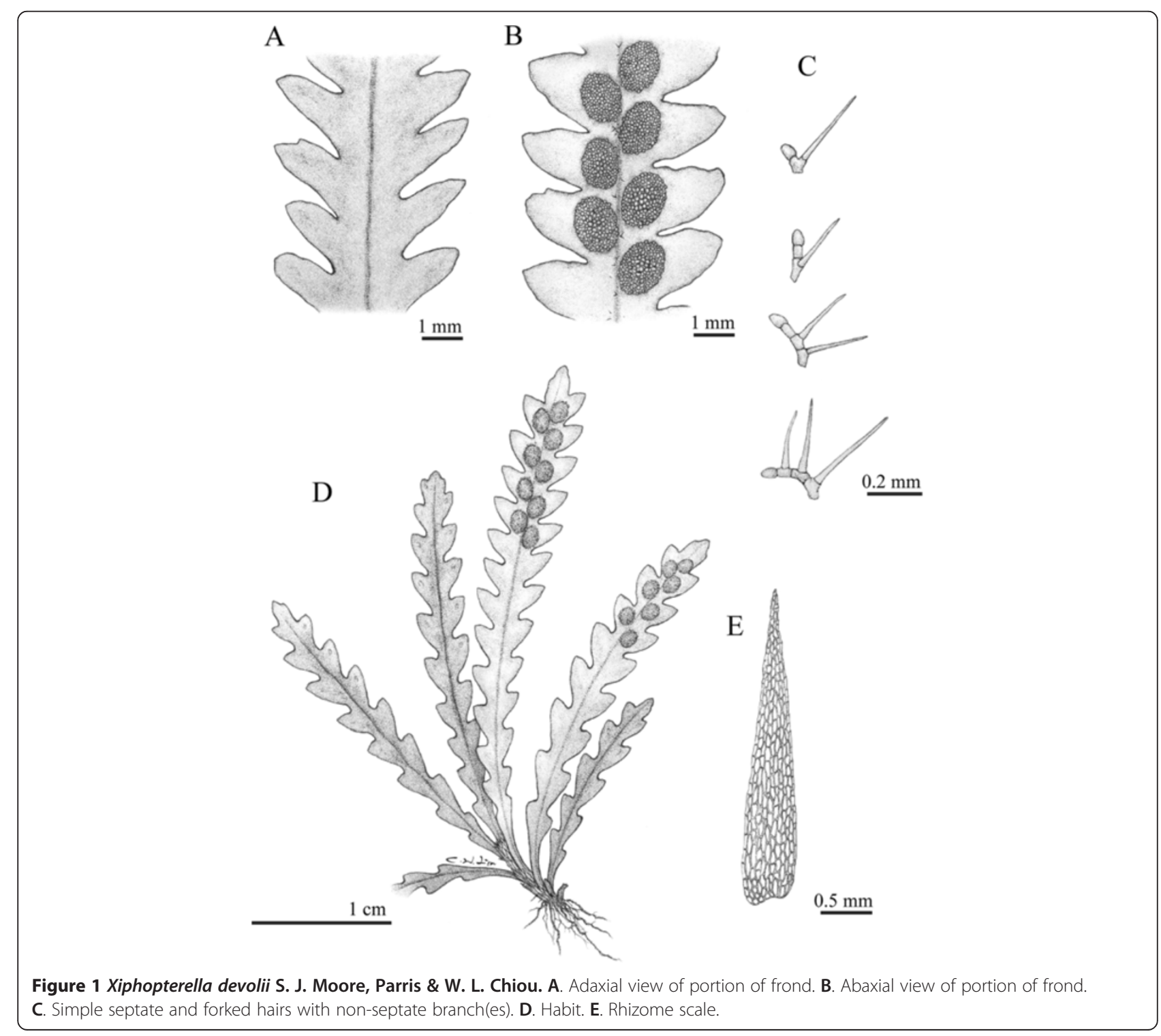



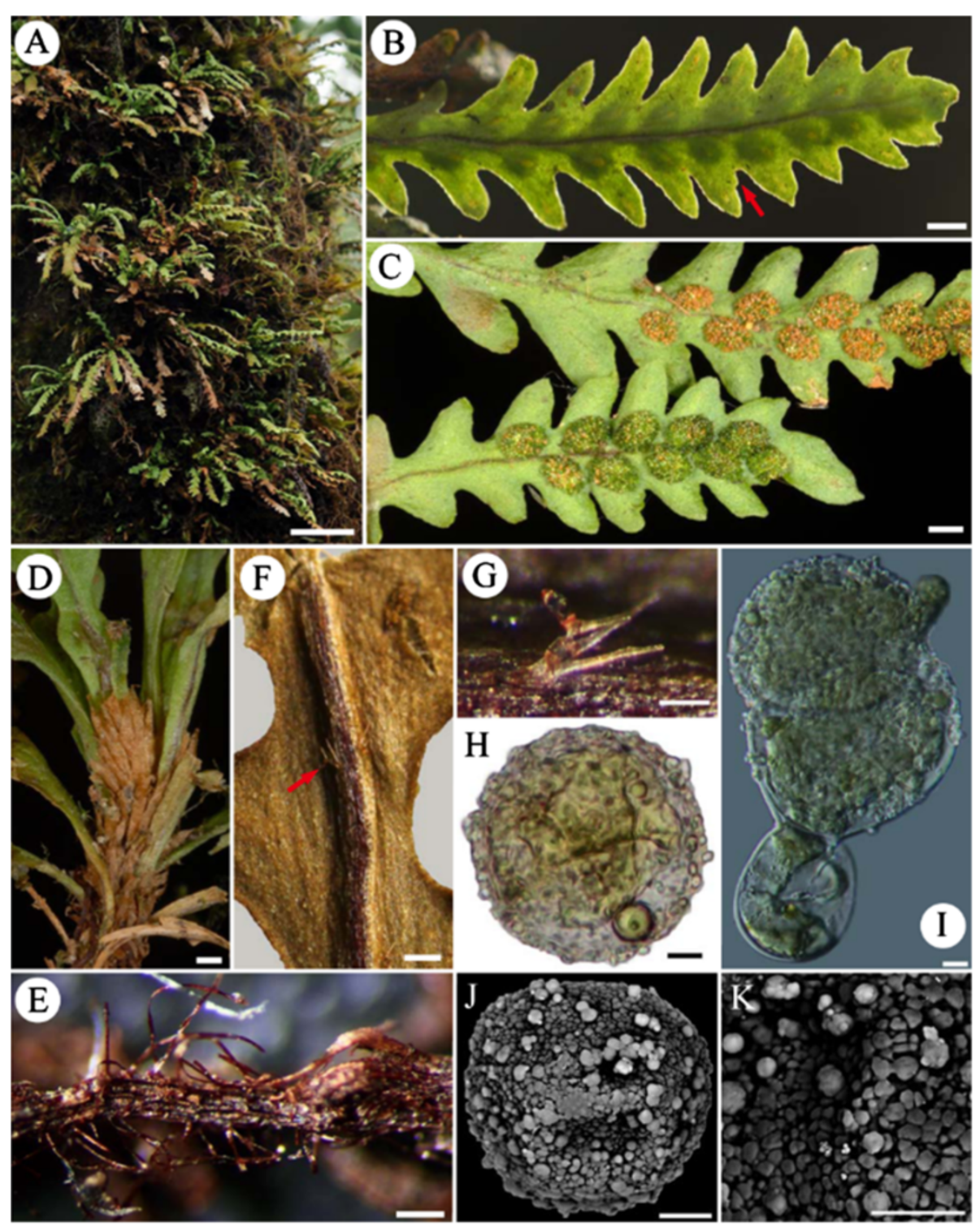

Figure 2 Xiphopterella devolii S. J. Moore, Parris \& W. L. Chiou. A. Habit and habitat (bar $=30 \mathrm{~mm})$. Small epiphytes growing on tree trunks in dense moist forest. B. Adaxial view of fertile frond (bar $=1 \mathrm{~mm}$ ). Lateral vein forked, ended with a hydathode; segment margin entire, rarely with a blunt tooth at acroscopic margin (arrow). C. Abaxial view of fertile frond (bar $=1 \mathrm{~mm})$. Lower: mature sori with green spores. Upper: sporereleased sori. $\mathbf{D}$. Lower portion of plant showing brown scales on rhizomes $(\mathrm{bar}=0.5 \mathrm{~mm})$. $\mathbf{E}$. Portion of root with reddish hairs $(\mathrm{bar}=0.2 \mathrm{~mm})$. $\mathbf{F}$. Portion of lamina showing forked hairs (arrow) on abaxial midrib $(\mathrm{bar}=0.5 \mathrm{~mm}$ ). G. Simple septate and 3-forked hair with non-septate branches $($ bar $=0.1 \mathrm{~mm})$. H-K. Spores (bar $=5 \mu \mathrm{m})$. H. Light microscopic image (BF). I. Germinated spore found on specimen (DIC). J. SEM image (BE). K. Portion of spore surface. Papillate with sparse globules.

globose, $24.58 \pm 0.49 \mu \mathrm{m}$ in diameter, usually depressed, some germinate in sporangium, surface papillate with sparse globules.

\section{Additional specimens examined}

TAIWAN. I-Lan, Sunglo Lake, 13 May 1999, C. C. Chen 7260 (TAIF); same locality, 20 May 2006, T. C. Hsu 509 (TAIF); same locality, 30 July 2006, P. F. Lu 12177 (TAIF); same locality, 23 Aug 2009, P. F. Lu 18727_1 (TAIF).

\section{Distribution and ecology}

Taiwan and SE \& S China. In Taiwan, it grows on tree trunks in dense moist forest; $1250-1350 \mathrm{~m}$ a.s.l.

\section{Etymology}

This new species is dedicated to Charles E. DeVol (19031989), a kind taxonomist who contributed to the research of Taiwanese lycophytes and ferns very much and was one of the editors for the Flora of Taiwan, 1st ed. 


\section{Discussion}

This new species was first discovered almost 15 years ago when it was suspected to be Grammitis cornigera (Baker) Ching or even a new species of Xiphopteris (Chen 1998). The species Ctenopterella cornigera (Baker) Parris (syn. Micropolypodium cornigerum (Baker) X. C. Zhang) is endemic to Sri Lanka. Many Chinese specimens (eg., PE 24845, PE 1366173, PE 02114785, PE 02185396) identified as Micropolypodium cornigerum (or Xiphopteris cornigera (Baker) Copel. and Grammitis cornigera (Baker) Ching) are in fact this new species. The 'Grammitis sp.' in Knapp (2011) is attributed to this new species, too.

\section{Conclusion}

Through detail comparison with previous literatures and specimens in worldwide herbaria, a grammitid fern is confirmed to be a new species, i.e., Xiphopterella devolii S. J. Moore, Parris, \& W. L. Chiou. Its types are designed and located herein. The Xiphopterella is a new recorded genus in Taiwan and is first found beyond Malesia regions.

\section{Competing interests}

The authors declare that they have no competing interests.

\section{Authors' contributions}

SJM first found this new species and drafted the manuscript; BSP confirmed this new species and gave the taxonomic treatment; TTK carried out the light microscope and SEM observation of morphology and took photos; PFL gave more detail distribution of this species, provided habit and habitat photos, and corrected the drawing and text; WLC finished the manuscript and correspond this paper. All authors read and approved the final manuscript.

\section{Author details}

${ }^{1}$ Taiwan Society of Plant Systematics, 88, Ting-Chow Rd., Sec 4, Taipei 11677 Taiwan. ${ }^{2}$ Fern Research Foundation, 21 James Kemp Place, Kerikeri, Bay of Island 0230, New Zealand. ${ }^{3}$ Taiwan Forestry Research Institute, 53 Nan Hai Road, Taipei 10066, Taiwan.

Received: 4 September 2012 Accepted: 27 March 2013

Published: 30 August 2013

\section{References}

Chen CC (1998) Study on the vegetation of Sunglo Lake watershed. Master thesis, Graduate Inst. Forest, Chung-Hsing University, Taichung, Taiwan

DeVol CE (1975) Grammitidaceae. In: Li HL et al. (ed) Flora of Taiwan, 1st edition, vol 1. Epoch Pub. Co. Ltd., Taipei, Taiwan, pp 216-230

Knapp R (2011) Ferns and Fern Allies of Taiwan. KBCC Press \& Yuan-Liou Pub, Taipei, Taiwan, p 239

Kuo CM (1985) Taxonomy and phytogeography of Taiwanese pteridophytes. Taiwania 30:5-99

Lu SG, Yang TYA (2005) The checklist of Taiwanese pteridophytes following Ching's system. Taiwania 50:137-165

Parris BS (2007) Five new genera and three new species of Grammitidaceae (filicales) and the re-establishment of Oreogrammitis. Gard Bull Sing $58: 233-274$

Schneider H, Smith AR, Cranfill R, Hildebrand TJ, Haufler CH, Ranker TA (2004) Unraveling the phylogeny of polygrammoid ferns (Polypodiaceae and Grammitidaceae): exploring aspects of the diversification of epiphytic plants. Mol Phyl Evol 31:1041-1063

Schuettpelz E, Pryer KM (2007) Fern phylogeny inferred from 400 leptosporangiate species and three plastid genes. Taxon 56:1037-1050

Shieh WC, Chiou WL, DeVol CE (1994) Grammitidaceae. In: Huang TC (ed) Flora of Taiwan, 2nd edition, vol 1. Editorial Committee of the Flora of Taiwan, second edition, Taipei, Taiwan, pp 520-534
Sundue MA, Melissa BI, Ranker TA (2010) Systematics of grammitid ferns (polypodiaceae): using morphology and plastid sequence data to resolve the circumscriptions of melpomene and the polyphyletic genera Lellingeria and Terpsichore. Syst Bot 35:701-715

Yang YP, Liu HY (2002) Manual of Taiwan vascular plants, vol 6. The Council of Agriculture Press, Taipei, Taiwan, p 665

doi:10.1186/1999-3110-54-24

Cite this article as: Moore et al:: Xiphopterella devolii (Polypodiaceae), a new species and newly recorded genus in Taiwan. Botanical Studies $201354: 24$.

\section{Submit your manuscript to a SpringerOpen ${ }^{\circ}$ journal and benefit from:}

- Convenient online submission

- Rigorous peer review

- Immediate publication on acceptance

- Open access: articles freely available online

- High visibility within the field

- Retaining the copyright to your article

Submit your next manuscript at springeropen.com 